\title{
GENDER AND SYLLABUS BASED STUDY APPROACHES AND ACADEMIC PERFORMANCES
}

\section{N A Chandana Jayawardena ${ }^{1 \& 2}$ and R H Kuruppuge ${ }^{2}$}

\begin{abstract}
The objective of the study was to examine the impact of gender-wise and syllabus-wise study approaches in academic performances of high school students. Study involved ninety high school students (45 girls, and 45 boys) randomly selected from two high schools in Galle, and Gampaha, Sri Lanka. Study process of respondents was measured by employing the 'revised two-factor Study Process Questionnaire' of Biggs et.al (2001). Descriptive and inferential analyses of data were conducted by using the SPSS software. The Study Approaches (including study motives, and study strategies) employed by respondents during the study process were examined. Relationships were tested among study process variables pertaining to the gender, and syllabus of respondents and their academic performances. High School girls have indicated deeper study methodologies in comparison to the boys. Science stream students recorded deeper study methodologies, and Arts stream students recorded surface study methodologies. Girls recorded superior examination results over boys. A positive relationship was found between the surface study approach and Academic performances of girls. Study highlights the necessity of defining, and applying integrated study process approaches, and evaluation techniques for the vitality of education.
\end{abstract}

${ }^{1}$ Tomaš Bata University in Zlin, Czech Republic ${ }^{2}$ University of Peradeniya, Sri Lanka chandanacj@gmail.com

ARTICLE INFO

Article type

Full research paper

doi: 10.7160/eriesj.2012.050301

Article history

Received: July 31, 2012

Received in revised form: September 25, 2012

Accepted: September 26, 2012

Available on-line: September 30, 2012

\section{Key Words}

Study Process Approaches, Gender, Syllabus, Academic Performances, High schools

Jayawardena, L. N. A. C., Kuruppuge R., H. (2012) “Gender and Syllabus Based Study Approaches and Academic Performance", Journal on Efficiency and Responsibility in Education and Science, Vol. 5, No. 3, pp. 115-124, ISSN 1803-1617, [on-line] www.eriesjournal.com/_papers/article_177.pdf [2012-09-30]. doi: 10.7160/eriesj.2012.050301 


\section{Introduction}

Success in higher education is an effective way of securing gainful employments, and career development for the youth. Bowles and Gintis (1999) have mentioned Education as an effective process of replicating work in producing future employees. Poropot (2011) has suggested 'integrating employability skills into education' as an important component 'of an overall agenda to groom students to become easily-integrated employees'. He has cautioned that the above efforts intended to promote the employability of students' could be misguided. Porpot (2011) elaborated further: 'if education is to fulfill its role in preparing students for work then employability should be integrated into normal educational practice, rather than added to it". He has further argued that the differences between the assessment of academic performances and workplace performances could diffuse the focus on employability through education. It would be pertinent to discuss about 'Teaching' and the role of teachers' in this respect. Schmulian and Coetzee (2011) have emphasized the importance of teaching style, and accountability of the 'appropriateness of their style of pedagogy' for the results tro ascertain the 'value addition' in classroom. They highlighted the vested interests of the stakeholders in a student's academic performance and that they pay attention to the "indicators demonstrating the possible value being added by a student's class attendance'. Marburger (2001) has emphasized the importance of guidance provided by a lecturer in facilitating the critical thought process. Thereby, the resultant line of questioning (and thinking) is facilitated in classroom learning. Class notes also provide a useful information source making attendance rewarding to the participants.

\section{Learning Styles}

Armstrong (1999) found a relationship between students' academic performances, and their stylistic preferences. In his study, analytic students have obtained superior grades over intuitive students. An association has been observed between the levels of individualism of students and their preferred learning styles (Sugahara and Boland, 2010). A study was conducted by Whitmire (2001) in regarding the performance measures of academic library performance, and the usage of library by undergraduates. Study did not reveal a strong relationship between the usage of library and students' academic performances. Cassidy and Eachus (1999) conducted a study among 130 undergraduates specialised in Health and social Policy. Study revealed relationships between students' approaches to achievement with their learning approaches. 'Strategic' learning approach correlated positively, and 'surface' approach correlated negatively with achievement. Van Zwanenberg et al. (1999) did not report relationships between academic performance and learning styles. Spicer (2004) has underlined the importance of providing the opportunity to students to explore individual cognitive style and learning approaches. He further elaborates' this, itself, is the first step to individuals gaining a potentially much deeper awareness and control of their approaches to learning and cognition, and thereby achieving a truly meta-cognitive understanding'.

\section{Study Process}

There are many theories about studying and learning. It has been common understanding that studying is a process, involving steps. 'Students approaches to learning' (SAL) theory (Entwistle, and Waterson, 1988 and Biggs, 1993) is a metatheory conceptualizing both teaching and learning. The ' $3 \mathrm{P}^{\prime}$ 
model of teaching and learning (Biggs, Kembler, and Leung, 2001) consists of three levels, viz. a Presage, Process, and a Product. Presage level describes the individual differences within a given teaching context, focused on 'Student factors' and the 'Teaching Context'. Process signifies the handling of specific tasks, based on 'learning focused activities'. Product level describes the differences of teaching contexts from each other. 'The heart of the teaching/ learning system is at the process level, where the learning related activity produces or does not produce the desired outcomes'(Biggs, Kembler, and Leung, 2001). In a study environment the roles of both the teacher and the student are vital for effectiveness. Researchers suggest that the involvement (and the output) of the student is more important than the teachers role, and the significance of the study approaches is focused. Biggs (1999) has elaborated on Deep, and the Surface Study approaches: 'A generic way of describing 'what the student does' is precisely in terms of their ongoing approaches to learning'. A student who a chance out likely items for assessment and rote learns them may fail in his strategy for portfolio assessment. Another student, who usually interacts deeply, may decide to go surface in a module overloaded with content and assessed by poorly constructed MCQs. The study approach is closely linked to the 'motive', and the 'strategy' chosen by a student.

\section{Scope of the study}

The research questions of the study posit; Are there relationships between the gender-wise study processes, and syllabus-wise study processes with students' academic performances? Overall objective of the study was to examine the gender-wise and syllabus-wise relationships of Sri Lankan high school students' with their study process and academic performances. The specific objectives of the study were to assess and analyze the impact of gender, and syllabus (offered by students) to the study approaches, motives, and strategies, and to the effectiveness of academic performances of high school students. Conceptual framework of the study is shown in Figure 1. By conducting this study in Sri Lanka, an attempt is made to extend the theory to a culture that is more collectivist in nature than that of the west. Herein the Hofstede's cultural dimensions theory (Wikipedia, 2012) enhances the validity of the research. Study also adds value for the vitality of educational systems.

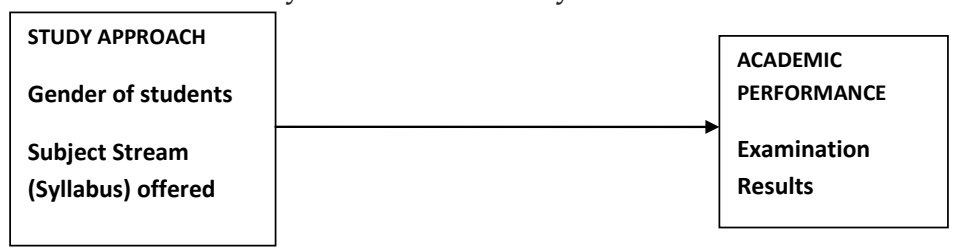

Figure 1. Conceptual framework of the Study

\section{Major Variables of Study}

Study consisted of two independent variables (e.g. Genderwise, and subject streams/syllabus-wise study approach of respondents), and the dependant variable, being the Academic Performance of the respondents (e.g. examination results). Study approach has been sub-divided into two levels; viz: Surface study approach, and Deep study approach. Further, each of these two study approaches consists of study motives, and study strategies.

\section{Sri Lankan Education System}

Sri Lanka education system derives from the British educational system introduced in the $19^{\text {th }}$ century. British colonial government established colleges for boys and girls separately. These colleges consisted of Primary Schools, Lower Secondary and Higher Secondary Schools. In 1938 the education in 
Government schools were made free of charge as a consequence of the Universal Franchise granted in 1931. As shown in Table 1, Primary education lasts for five years, followed by the Junior Secondary, and Secondary education lasting for four, and two years, respectively. Next, students appear for the government examination namely G.C.E. ordinary level. Senior Secondary education is followed by for two years. Students then sit for the competitive university entrance examination, called G.C.E. Advanced level (A-Level) examination. Those who are not admitted to the universities can either enter vocational technical schools or be employed in companies or in government departments as apprentices or trainees.

\begin{tabular}{|l|c|c|}
\hline Stage & Grades & No of years \\
\hline Primary & $1-5$ & 5 \\
\hline Junior Secondary & $6-9$ & 4 \\
\hline Secondary (GCE / Ordinary Level) & $10-11$ & 2 \\
\hline $\begin{array}{l}\text { Senior Secondary/ Collegiate (GCE / } \\
\text { Advanced Level) }\end{array}$ & $12-13$ & 2 \\
\hline
\end{tabular}

Table 1: Time structure of school education structure in Sri Lanka (Source: National Report, 2004, Ministry of Education, Sri Lanka pp. 1-3.)

\section{High School Education Structure in Sri Lanka}

Senior secondary education in Sri Lanka serves in preparing students for a very competitive examination in selection to state universities at the end of two years. General Certificate of Education (GCE/ AL) qualification is conducted by the Department of Examinations of the Ministry of Education. It is similar to the British Advanced Level, and is usually taken by students at the end of the final two years of Collegiate level (Grades 12, and 13). A student has three attempts and they can face the exam as an external (non-school) candidate also. A-Level examination serves as an entrance qualification to state universities, practicing free education. Examinations are held in the three mediums of Sinhala, Tamil and English. Students usually sit the examination in first attempt at the age of 19 .

A-Level examination diversifies over 4 major fields of study, namely:

1. Physical Science Stream (Combined mathematics, Physics and Chemistry)

2. Biological Science Stream (Biology (Botany and Zoology), Physics and Chemistry)

3. Commerce and Accounting Stream, and 4. Arts Stream

In each stream, students have to take 3 subjects. Additionally there is a General English test and a Common General test, and students have to ensure obligatory passes. (Wikipedia, the free encyclopaedia, 2012)

\section{Materials and Methods}

\section{The Study Process Questionnaire}

The Study Process Questionnaire (SPO) had been developed, based on a Study Behaviour Questionnaire by the author (Biggs, 1993). It has focused on three dimensions of learning: viz; Surface, Deep, and Achieving (refer Table 2). Each 'study approach' has a specific 'motive', and an underlying 'strategy'. The revised two-factor SPQ (Revised-SPQ-2F) is an established measure developed by Biggs, Kembler, and Leung in 2001. It has focused on 'surface', and 'deep' approaches, having 10 items to focus on each approach. The two main factors (e.g. deep and surface) have distinguished the motive, and strategy sub components. 


\begin{tabular}{|l|c|c|c|}
\hline Parameter & Surface & Deep & Achieving \\
\hline Motive & Fear of failure & $\begin{array}{c}\text { Intrinsic } \\
\text { interest }\end{array}$ & Achievement \\
\hline Strategy & $\begin{array}{c}\text { Narrow target, rote } \\
\text { learn }\end{array}$ & $\begin{array}{c}\text { Maximise } \\
\text { meaning }\end{array}$ & $\begin{array}{c}\text { Effective use } \\
\text { of space and time }\end{array}$ \\
\hline
\end{tabular}

Table 2. The Study Process Questionnaire: Dimensions, motives and strategies (Source: Study Process Questionnaire, Biggs et al., 2001)

\section{Operationalisation of the Study}

Two high schools situated in the cities of Galle, and Gampaha in Sri Lanka were selected for the study. Ninety high school students, (45 girls, and boys each) were randomly selected. They were preparing to sit for the A-Level examination in August this year (2012). These students have selected three different syllabuses (subject streams); viz: Science, Commerce, and Arts. There were thirty (30) respondents each following these subject streams. Revised-SPQ-2F instrument was employed to compile the questionnaire, for its merit and simplicity of the construct. Respondents' academic performance was measured based on their results at the 2011 December examinations. Statements (of the Revised-SPQ-2F) were translated into Czech language, and slight modifications were made (after pre-testing) to improve clarity. Authors (native Sinhala language speakers) were available for clarifications. Students were briefed of the purpose of research, and the confidentiality of their responses was assured. Questionnaires were administered in groups for self responses on the basis of anonymity. SPSS computer software was used for the descriptive and inferential data analysis. Regression and Correlation analysis were conducted to test the relationship among the study variables.

\section{Results and Discussion}

Respondents' age ranged from 17 years to 19 years, and the majority was 18 years old. Thirty respondents each belonged to three different subject streams/syllabus, namely Science, Commerce, and Arts, and they were equal (fifteen each) in gender proportions.

\section{Study approach of students}

Respondents scores for the two major independent variables, namely Surface Study approach (SA), and Deep Study approach (DA) using the Revised-SPQ-2F are depicted in Table 3.

\begin{tabular}{|l|c|c|c|c|c|c|}
\hline Parameter & Overall & Boys & Girls & $\begin{array}{c}\text { Science } \\
\text { stream } \\
\text { students }\end{array}$ & $\begin{array}{c}\text { Commerce } \\
\text { stream } \\
\text { students }\end{array}$ & $\begin{array}{c}\text { Arts stream } \\
\text { students }\end{array}$ \\
\hline Mean & 30.18 & 31.64 & 28.68 & 28.93 & 29.53 & 32.14 \\
\hline $\begin{array}{l}\text { Std. } \\
\text { Deviation }\end{array}$ & 6.70 & 5.68 & 7.36 & 7.41 & 6.12 & 6.26 \\
\hline
\end{tabular}

Table 3. Surface study approach of respondents (Source: Authors')

A Mean (M) value of 30.18 has been recorded for SA. Boys have scored a higher $M$ value of 31.64 than girls (28.68) for SA. Arts stream students had recorded the highest scores for SA compared to the students of Science and Commerce streams.

\begin{tabular}{|l|c|c|c|c|c|c|}
\hline Parameter & Overall & Boys & Girls & $\begin{array}{c}\text { Science } \\
\text { stream } \\
\text { students }\end{array}$ & $\begin{array}{c}\text { Commerce } \\
\text { stream } \\
\text { students }\end{array}$ & $\begin{array}{c}\text { Arts } \\
\text { stream } \\
\text { students }\end{array}$ \\
\hline Mean & 32.02 & 33.02 & 31.00 & 32.33 & 32.17 & 31.55 \\
\hline $\begin{array}{l}\text { M } \\
\text { (DSA-SSA) }\end{array}$ & 1.84 & 1.38 & 2.32 & 3.40 & 2.64 & -0.59 \\
\hline $\begin{array}{l}\text { Std. } \\
\text { Deviation }\end{array}$ & 5.71 & 4.04 & 6.92 & 5.49 & 5.68 & 6.13 \\
\hline
\end{tabular}

Table 4. Deep study approach of respondents (Source: Authors') 
A Mean value of 32.02 has been recorded by the respondents for DA (refer Table 4). Boys have recorded a higher value for DA $33.02(\mathrm{M})$ over girls $31.00(\mathrm{M})$. However, girls indicated a higher net value (2.32) for the use of DA over SA in comparison to Boys (1.38). This may have been reflected in the higher number (and percentage) of female students securing university admissions in Sri Lanka. Science stream students recorded the highest net value of $3.40(\mathrm{M})$ for the use of DA over SA in compared to others. It was followed by the Commerce stream students' net value of $2.64(\mathrm{M})$. Arts stream students' $-0.59(\mathrm{M})$ indicated a reliance on SA over DA. It was note-worthy that the Arts stream students were the only notable exception. This could be an indication of the nature and demands of those subject streams.

\section{Study Motives of Respondents}

The sub variables of the study process (motives, and strategies) were measured. Study motives were further sub divided as Surface study motive, and Deep study motive.

\begin{tabular}{|l|c|c|c|c|c|c|}
\hline Parameter & Overall & Boys & Girls & $\begin{array}{c}\text { Science } \\
\text { stream } \\
\text { students }\end{array}$ & $\begin{array}{c}\text { Commerce } \\
\text { stream } \\
\text { students }\end{array}$ & $\begin{array}{c}\text { Arts } \\
\text { stream } \\
\text { students }\end{array}$ \\
\hline Mean & 13.09 & 13.44 & 12.73 & 13.10 & 12.40 & 13.79 \\
\hline $\begin{array}{l}\text { Std. } \\
\text { Deviation }\end{array}$ & 3.63 & 3.19 & 4.03 & 3.68 & 3.22 & 3.94 \\
\hline
\end{tabular}

Table 5. Surface study motive of respondents (Source: Authors')

Table 5 depicts the Surface Study Motives (SSM) of the respondents. Mean values of 13.44, and 12.73 were recorded by the boys, and girls for the SSM. Arts streams students recorded a higher $M$ value for the SSM over those following Science and Commerce subject streams.

\begin{tabular}{|l|c|c|c|c|c|c|}
\hline Parameter & Overall & Boys & Girls & $\begin{array}{c}\text { Science } \\
\text { stream } \\
\text { students }\end{array}$ & $\begin{array}{c}\text { Commerce } \\
\text { stream } \\
\text { students }\end{array}$ & $\begin{array}{c}\text { Arts } \\
\text { stream } \\
\text { students }\end{array}$ \\
\hline Mean & 15.62 & 15.71 & 15.52 & 16.00 & 15.67 & 15.17 \\
\hline $\begin{array}{l}\text { M } \\
\text { (DSM-SSM) }\end{array}$ & 2.53 & 2.27 & 2.79 & 2.90 & 3.27 & 1.38 \\
\hline $\begin{array}{l}\text { Std. } \\
\text { Deviation }\end{array}$ & 3.39 & 2.46 & 4.17 & 3.56 & 2.82 & 3.80 \\
\hline
\end{tabular}

Table 6. Deep study motive of respondents (Source: Authors')

Table 6 depicts the scores for the Deep Study Motive (DSM) of respondents. Boys have recorded a M value of 15.71 for DSM. Girls have recorded a M value of 15.52 for same. Girls have shown a slightly higher net value of $2.79(\mathrm{M})$ for deeper study motive (DSM-SSM) over boys. This was in agreement with the findings depicted in Tables 3, and 4. Respondents following Arts subject streams showed the least M value (1.38) for DSM over SSM. This may again indicate the perception among the Sri Lankan adolescents of Arts stream subjects.

\section{Study Strategies of Respondents}

Study Strategies employed by the respondents during study process were measured. Strategies were sub divided as 'Surface' and 'Deep'.

\begin{tabular}{|l|c|c|c|c|c|c|}
\hline Parameter & Overall & Boys & Girls & $\begin{array}{c}\text { Science } \\
\text { stream } \\
\text { students }\end{array}$ & $\begin{array}{c}\text { Commerce } \\
\text { stream } \\
\text { students }\end{array}$ & $\begin{array}{c}\text { Arts stream } \\
\text { students }\end{array}$ \\
\hline Mean & 17.09 & 18.20 & 15.95 & 15.83 & 17.13 & 18.34 \\
\hline $\begin{array}{l}\text { Std. } \\
\text { Deviation }\end{array}$ & 4.04 & 3.33 & 4.40 & 4.42 & 4.26 & 2.98 \\
\hline
\end{tabular}

Table 7. Surface study strategy of respondents (Source: Authors') 
Study Strategies of the respondents were assessed. As depicted in Table 7, boys recorded a higher value $18.20(\mathrm{M})$ over girls $15.95(\mathrm{M})$ for Surface Study Strategies (SSS) adopted in the study process. Arts stream respondents recorded the highest value of $18.34(\mathrm{M})$ for SSS over Science and Commerce stream students. This was more aligned with the scores recorded by Arts stream students for Study Motives.

\begin{tabular}{|l|c|c|c|c|c|c|}
\hline Parameter & Overall & Boys & Girls & $\begin{array}{c}\text { Science } \\
\text { stream } \\
\text { students }\end{array}$ & $\begin{array}{c}\text { Commerce } \\
\text { stream } \\
\text { students }\end{array}$ & $\begin{array}{c}\text { Arts stream } \\
\text { students }\end{array}$ \\
\hline Mean & 16.40 & 17.31 & 15.48 & 16.33 & 16.50 & 16.38 \\
\hline $\begin{array}{l}\text { M } \\
\text { (DSS-SSS) }\end{array}$ & -0.69 & -0.89 & -0.47 & 0.50 & -0.63 & -1.96 \\
\hline $\begin{array}{l}\text { Std. } \\
\text { Deviation }\end{array}$ & 3.44 & 3.04 & 3.60 & 2.80 & 3.90 & 3.65 \\
\hline
\end{tabular}

Table 8. Deep study strategy of respondents (Source: Authors')

Mean values of 17.31 and 15.48 were recorded by Boys and Girls respectively for Deep Study Strategy (DSS) (Refer Table 8). It was note-worthy that respondents (both by girls and boys) recorded negative values for DSS over SSS. This suggested a dependence in surface study strategies, despite expressing a liking towards Deeper study motives. Arts stream students indicated the highest dependence on SSS with a negative net value of 1.96 over DSS. This was affirmative of the inclination indicated by them compared with other stream students.

\section{Academic Performance of respondents}

Academic performances of the respondents were assessed based on the marks obtained by them at the end of year examination in December, 2011. Students have faced three subjects from their major stream; viz: Science, Commerce, Arts. Respondents' marks for the three main subjects have been averaged and shown as a percentage in Table 9. Girls have scored higher 64.34 (M) than boys $58.80(\mathrm{M})$ at the examination.

\begin{tabular}{|l|c|c|c|c|c|}
\hline Parameter & Boys & Girls & $\begin{array}{c}\text { Science stream } \\
\text { students }\end{array}$ & $\begin{array}{c}\text { Commerce } \\
\text { stream students }\end{array}$ & $\begin{array}{c}\text { Arts stream } \\
\text { students }\end{array}$ \\
\hline Mean (M) & 58.80 & 64.34 & 62.00 & 57.89 & 64.30 \\
\hline $\begin{array}{l}\text { Std. } \\
\text { Deviation }\end{array}$ & 9.39 & 11.12 & 7.38 & 8.71 & 13.96 \\
\hline
\end{tabular}

Table 9. Marks obtained by respondents as a percentage (Source: Authors')

Marks of respondents were analysed based on their respective subject streams. Arts stream students scored the highest value $64.30(\mathrm{M})$. This was seemingly in contrast to their scores recorded for Study process variables. This indicated that the Arts stream students' reliance on surface study approaches has been more effective in contrast with the study approaches adopted by the Science and Commerce stream students. It may also suggest that rote learning approach has been more effective to secure better results for Arts stream subjects. Whereas, this may be the opposite to secure better grades in other streams, especially of Science-based.

\section{Significant Relationships}

Relationships of the respondents between Gender-wise study approaches and Academic Performances, and Subject streamwise (Syllabus) study approaches and Academic performances were tested using two nested models of linear regression. Study approaches were analyzed for Deep Approach and Surface Approach. Accordingly, the following relationships were tested. Deep Study Approach (DSA), and Surface Study Approach (SSA) of boys and girls with their Academic performances (AP). Deep Study Approach, and Surface Study Approach of subject stream-wise respondents with their Academic performances. 
In the accompanying equation of $\mathrm{Yi}=\mathrm{bo}+\mathrm{biX}$, for linear regression, $\mathrm{Y}$ was the Academic performances of respondents, and $\mathrm{X}$ was the Study Apparoach used by them..

\section{I.) Nested Model: Gender-wise Study Approaches and Academic Performances}

a) Surface Study Approach of boys and their academic performances: There was no significant relationship. The Pearson correlation value (r) was 0.159 .

b) Surface Study Approach of girls and their Academic performances: There was a positive relationship, which can be summarized by the following equation: Academic Performances of girls $=47.973+0.578 *$ SSA of girls. The Pearson correlation value (r) of 0.359 between SSA and AP, and the corresponding $\mathrm{R}^{2}$ value of 0.129 indicated that SSA of girls contributes to $12.9 \%$ of their AP. F value of 5.48 confirmed the strength of this model. The gradient of the regression line was a moderate 0.578 , with a corresponding t value of 2.342 significant at 0.025 level (2-tailed).

c) Deep Study Approach of boys and their academic performances: There was no significant relationship. The Pearson correlation value (r) was 0.103 .

d) Deep Study Approach of girls and their academic performances: There was no significant relationship. The Pearson correlation value (r) was 0.111.

\section{II.) Nested Model: Subject stream-wise Study Approaches and Academic Performances}

a) Surface Study Approach of Science students and their Academic performances : There was no significant relationship. The Pearson correlation value (r) was 0.059 . b) Surface Study Approach of Commerce students and their Academic performances: There was no significant relationship. The Pearson correlation value (r) was 0.003 .

c) Surface Study Approach of Arts students and their Academic performances: There was no significant relationship. The Pearson correlation value (r) was 0.065 .

d) Deep Study Approach of Science students and their Academic performances: There was no significant relationship. The Pearson correlation value ( $\mathrm{r}$ ) was 0.016 .

e) Deep Study Approach of Commerce students and their Academic performances: There was no significant relationship. The Pearson correlation value $(r)$ was 0.129 .

f) Deep Study Approach of Arts students and their Academic performances: There was no significant relationship. The Pearson correlation value (r) between DSA and AP was 0.134.

The Academic performances of respondents were tested for relationship with the following study process dimensions; viz: a.) Study Approach, b.) Study Motive, and c.) Study Strategy. Significant relationships were not recorded between Academic Performances of Respondents and any of the abovementioned study process dimensions. Following correlations were noted. However, they were of moderate strength.

Marks obtained by Sri Lankan Girls with their Surface Study Approach (Pearson Correlation coefficient 0.359, at 0.025), Correlation is significant at the 0.05 level (2-tailed).

Marks obtained by Sri Lankan Girls with their Surface Study Strategy (Pearson Correlation coefficient 0.434, at 0.006), Correlation is significant at the 0.01 level (2-tailed). 


\section{Conclusion}

Respondents (Sri Lankan high school students) had expressed a liking to 'Deep' study approaches, and motives over 'Surface' study approaches, and motives. However, they were over dependant (slightly) on 'Surface' study strategies. Herein, the study's findings are bit paradoxical. The Hofstede's cultural dimensions theory (Wikipedia, 2012) may have an impact in this context. The adoption of deeper study process methodologies by the high school girls (compared with the boys) may have resulted in their superior academic performances. It is noteworthy that a positive relationship was found between the Surface Study Approach and academic performances of girls. This makes an interesting finding. However, the absence of details of assessment techniques employed by the teachers and education systems, does not warrant further inferences. Science stream based students had adopted deeper study methodologies and the Arts stream based students were most dependant on surface study methodologies. This could depend on the nature, and demands of subject streams/syllabuses, and evaluation schemes as per the Bloom's Taxonomy of Learning (Forehand, 2005). It will make little practical sense to discuss the respondents' choice of 'Study Process approaches'in isolation sans abovementioned details. Study highlights the necessity of identifying, and applying appropriate study processes (Motives and Strategies) for the growth and effectiveness of education. It is recommended to have an integrated focus in designing syllabuses, teaching methods and evaluation techniques for greater sense and vitality of education.

\section{Limitations and Further research}

Study was conducted only among two groups of Sri Lankan high school students. Further research is recommended to be conducted among larger numbers of students in different phases of education, across geographical regions for generalization of findings. It is also suggested to conduct research having a study process approach to education, with focussed evaluation techniques (based on the curricula), especially at secondary and tertiary levels.

\section{Acknowledgements}

Authors are thankful to the Internal Grant Agency of FaME TBU No. IGA/FaME/2012/038 (Emotional Intelligence in adding value to academic performances and managerial effectiveness) for financial support to carry out this research.

\section{References}

Armstrong, S.J. (1999), “The influence of individual cognitive style on performance in management education", Proceedings of the 4th Annual Conference of the European Learning Styles Information Network, University of Central Lancashire, 28-29 June, pp. 31-50.

Biggs, J.B. (1993).'What do inventories of students' learning processes really measure? A theoretical review and clarification', British Journal of Educational Psychology pp. 1-17, 63. http://dx.doi.org/10.1111/j.2044-8279.1993.tb01038.x.

Biggs, J.B. (1999). 'Teaching for quality learning at University', Buckingham: Open university press.

Biggs, J.B. Kember, D. Leung, D.Y.P. (2001). The revised two-factor Study Process Questionnaire: R-SPQ-2F, British Journal of Educational Psychology, pp. 71, 133-149. http://dx.doi.org/10.1348/000709901158433. 
Bowles, S. and Gintis, H. (1999), 'Comments on the long shadow of work', Critical Sociology, Vol. 25, pp. 3-7. http://dx.doi.org/10.1177/08969205990250021601.

Cassidy, S. and Eachus, P. (1999), 'Learning style, academic belief systems, self-report student proficiency and academic achievement in higher education', Proceedings of the 4th Annual Conference of the European Learning Styles Information Network, University of Central Lancashire, 28-29 June, pp. 12540.

Entwistle, N. Waterston, S. (1988). 'Approaches to studying and levels of processing in university students', British Journal of Educational psychology, pp.58, 258 - 265. http://dx.doi.org/10.1111/j.2044-8279.1988.tb00901.x.

Forehand, M. (2005), Blooms Taxonomy: Original and Revised In. Orey, M (eds), Emerging Perspectives on Learning, Teaching, and Technology. Retrieved August 25, 2012, from http://projects. coe.uga.edu/epltt.

GCE Advanced Level in Sri Lanka, (2012, March, 31). Retrieved from Wikipedia, the free encyclopedia http://en.wikipedia.org/ wiki/GCE_Advanced_Level_in_Sri_Lanka.

Marburger, D.R. (2001), "Absenteeism and undergraduate exam performance", Journal of Economic Education, Vol. 32 No. 2, pp. 99-109. http://dx.doi.org/10.1080/00220480109595176.

National Report, (2004). The Development of Education, (pp. 1-3), Ministry of Education Sri Lanka.

Poropat, A. E. (2011), 'The role of citizenship performance in academic achievement and graduate employability', Education + Training, Vol. 53, No. 6, pp. 499-514. http://dx.doi.org/10.1108/00400911111159467.
Schmulian, A and Coetzee, S. (2011), 'Class absenteeism: reasons for non-attendance and the effect on academic performance', Accounting Research Journal, Vol. 24 No. 2, pp. 178-194. http://dx.doi.org/10.1108/10309611111163718.

Spicer, D. P. (2004), 'The impact of approaches to learning and cognition on academic performance in business and management', Education + Training, Volume $46 \cdot$ Number 4 , pp. 194-205. http://dx.doi.org/10.1108/00400910410543982.

Sugahara, S. and Boland, G. (2010), 'The role of cultural factors in the learning style preferences of accounting students: a comparative study between Japan and Australia', Accounting Education: An International Journal, Vol. 19 No. 3, pp. 235-55. http://dx.doi.org/10.1080/09639280903208518.

Van Zwanenberg, N., Wilkinson, L.J. and Anderson, A. (1999), 'Felder and Silverman's Index of Learning Styles and Honey and Mumford's Learning Styles Questionnaire: how do they compare and do they predict academic performance?', Proceedings of the 4th Annual Conference of the European Learning Styles Information Network, University of Central Lancashire, 28-29 June, pp. 423-41.

Whitmire, E. (2001), 'The relationship between undergraduates' background characteristics and college experiences and their academic library use', College \& Research Libraries, Vol. 62 No. 6, pp. 528-40.

Wikipedia contributors. (2012, August 19). Hofstede's cultural dimensions theory, Wikipedia, the free encyclopedia, Wikimedia Foundation, Inc. Retrieved from http://en.wikipedia.org/w/

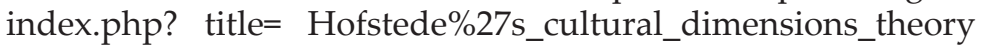
and oldid $=503581691$. 